\title{
Fever recurrence in intensive care depending on the cooling technique used
}

\section{Nawrót gorączki podczas intensywnej terapii w zależności od użytej metody schładzania pacjenta}

\author{
Kateřina HašováA-D,F, Andrea VilímkováA,E,F \\ Department of Haematooncology, University Hospital, Ostrava, Czech Republic \\ A - research concept and design; $\mathrm{B}$ - collection and/or assembly of data; $\mathrm{C}$ - data analysis and interpretation; \\ $D$ - writing the article; $E$ - critical revision of the article; $F$ - final approval of the article
}

Address for correspondence
Kateřina Hašová

E-mail: katerina.hasova@fno.cz

Conflict of interests

None declared

Received on December 10, 2017

Reviewed on January 8, 2018

Accepted on February 12, 2018

DOI

10.17219/pzp/85263

Copyright

○ 2018 by Wroclaw Medical University

This is an article distributed under the terms of the

Creative Commons Attribution Non-Commercial License

(http://creativecommons.org/licenses/by-nc-nd/4.0/)

\begin{abstract}
Background. From our experience, we know that after cooling the patient to normothermia, recurrence of fever is often observed within $24 \mathrm{~h}$. We have examined various factors influencing fever recurrence within $24 \mathrm{~h}$ after completion of cooling, such as the APACHE II score, use of antipyretics, sedation and patient age; nevertheless, these observations are not a part of this article.

Objectives. The main aim of the work was to compare the efficacy in decreasing fever and preventing its recurrence of using the Blanketrol III cooling device and cooling gel pads.

Material and methods. The required data was retrieved from patient medical records and recorded in the research protocol. A total of 60 patients were enrolled in our study, in whom a recurrence of fever was observed within $24 \mathrm{~h}$. The study subjects were divided into 2 numerically equal groups. The subjects in the experimental group were cooled using the Blanketrol III cooling device, while cooling gel pads were used in the control group. The decision regarding initiation of cooling and the use of antipyretics was at the discretion of the attending physician.
\end{abstract}

Results. Comparison of the 2 groups of the observed study subjects showed that recurrence of fever was observed within $24 \mathrm{~h}$ after completion of the cooling procedure in $80 \%$ of patients in Group 1, and in $73.33 \%$ of patients in Group 2. Analysis of the data revealed no statistically significant difference in fever recurrence between the 2 groups.

Conclusions. The authors found that the rate of fever recurrence was approximately identical in both groups studied. It is thus possible to conclude that no difference in results exists between cooling the patients with the Blanketrol III device, utilizing a blanket with circulating water placed on the entire body surface of the patient, and the use of cooling gel pads placed on the groin area, the axilla and near the head.

Key words: fever, external cooling, antipyretics, Blanketrol III cooling device, cooling gel pads 


\section{Streszczenie}

Wprowadzenie. Z naszego doświadczenia wiemy, że po schłodzeniu pacjenta do normotermii nawrót gorączki często obserwuje się w ciągu 24 godzin. Zbadaliśmy różne czynniki wpływające na nawrót gorączki w ciągu 24 godzin po zakończeniu chłodzenia, takie jak punktacja APACHE Il, stosowanie leków przeciwgorączkowych, uspokojenie polekowe i wiek pacjenta; niemniej jednak obserwacje te nie są częścią tego artykułu.

Cel pracy. Głównym celem pracy było porównanie skuteczności zmniejszania gorączki i zapobiegania jej nawrotom za pomocą urządzenia chłodzącego Blanketrol III i płytek żelowych.

Materiał i metody. Wymagane dane zostały pobrane z dokumentacji medycznej pacjenta i zapisane w protokole badawczym. Do naszego badania włączono ogółem 60 pacjentów, u których w ciągu 24 godzin zaobserwowano nawrót gorączki. Badani zostali podzieleni na 2 równe grupy. Osoby w grupie eksperymentalnej schłodzono za pomocą urządzenia chłodzącego Blanketrol III, w grupie kontrolnej zastosowano podkładki żelowe. Decyzję o rozpoczęciu chłodzenia i stosowaniu leków przeciwgorączkowych pozostawiono lekarzowi prowadzącemu.

Wyniki. Porównanie 2 obserwowanych grup uczestników badania wykazało, że nawrót gorączki zaobserwowano w ciągu 24 godzin od zakończenia procedury chłodzenia u 80\% pacjentów w grupie 1 oraz u 73,33\% pacjentów w grupie 2. Analiza danych nie wykazała istotnych statystycznie różnic w nawrocie gorączki między obiema grupami.

Wnioski. Autorzy stwierdzili, że częstość nawrotu gorączki była w przybliżeniu taka sama w obu badanych grupach. Można stwierdzić, że nie ma żadnej różnicy między chłodzeniem pacjentów z wykorzystaniem urządzenia Blanketrol III przy użyciu koca z cyrkulującą wodą umieszczoną na całej powierzchni ciała pacjenta a zastosowaniem ochładzających podkładek żelowych umieszczonych w okolicy pachwiny, pachy i blisko głowy.

Słowa kluczowe: gorączka, chłodzenie zewnętrzne, środki przeciwgorączkowe, urządzenie chłodzące Blanketrol III, podkładki żelowe

\section{Background}

Fever presents a common problem in patients hospitalized at intensive care units. It is estimated that nosocomial fever occurs in approx. $1 / 3$ of all patients during their stay in a hospital. ${ }^{1}$ Fever is observed in more than $90 \%$ of patients with severe sepsis hospitalized at intensive care units. ${ }^{2}$ In clinical practice, various techniques of external cooling are used to treat fever. The most frequently applied techniques include the use of lukewarm or cold sponges, ice-cold gel pads, and cooling blankets, as well as blowing of cold air. A number of complications and adverse events may be observed when using external cooling. Several authors also mention the rebound phenomenon of fever in their studies. ${ }^{3,4}$

The main aim of this work was to compare the efficacy in decreasing fever and preventing its recurrence of using the Blanketrol III cooling device and cooling gel pads.

\section{Material and methods}

The data was collected between January 1, 2012 and November 30, 2012. The study was performed at intensive care units of the Ostrava University Hospital, Czech Republic, and at the Anesthesiology-Resuscitation Department of the Ostrava Municipal Hospital, Czech Republic. The research project was approved by both institutions. The data was processed in accordance with the applicable ethical standards; the anonymity of the study subjects was not violated in any way. A total of 60 patients were enrolled in the prospective research project. All study subjects were intubated in the emergency room and treated with antibiotics. The patients were divided into 2 groups. The experimental group consisted of $30 \mathrm{pa}$ tients from the Ostrava University Hospital, who were cooled using the external Blanketrol III cooling device. The control group consisted of 30 patients who were cooled with external cooling gel pads. The study subjects in the control group were hospitalized at the Anesthesiology-Resuscitation Department of the Ostrava Municipal Hospital. Cooling was applied in both groups for a period of at least $48 \mathrm{~h}$.

The study subjects enrolled in the study fulfilled the following inclusion criteria: selected indicators of sepsis - fever over $38.3^{\circ} \mathrm{C}$, tachycardia, leukocytosis, and further administration of cooling using the Blanketrol III cooling device or cooling gel pads, fever recurrence within $24 \mathrm{~h}$, and being monitored during the first attack of sepsis. We excluded patients with cranial trauma, patients after surgical procedures ( $<96 \mathrm{~h}$ from surgery), and patients with recurrent attacks of sepsis. ${ }^{5}$ General nurses measured the body temperature with a digital thermometer (Ostrava Municipal Hospital), or contact mercury-free glass thermometer (Ostrava University Hospital). The data was retrieved from the patients' medical records and recorded in the research protocol. The research protocol consisted of several sections, and was aimed at the collection of demographic data - patient age and sex, and measurement of current APACHE II score at the beginning of cooling. Furthermore, data concerning the administration of sedation and antipyretic medication was recorded, including times of administration. A part of the protocol was also recording the duration of cooling before normothermia was achieved, occurrence of fever recurrence, and the time period between cooling and fever recurrence. 


\section{Results}

A total of 60 patients were enrolled in the study; the study subjects were divided into 2 groups, depending on the cooling technique used. Group 1 consisted of 30 patients, who were cooled using the Blanketrol III cooling device; 22 (73\%) men and 8 (27\%) women (Table 1). Group 2 consisted of 30 patients, cooled using cooling gel pads; 18 (60\%) men and 12 (40\%) women (Table 2).

Table 1. Descriptive statistics - Group 1

Tabela 1. Charakterystyka opisowa - grupa 1

\begin{tabular}{|l|r|r|r|l|}
\hline Item & M & SD & Min. & Max. \\
\hline Age [years] & 52.7 & 17.5 & 22.0 & 85.0 \\
APACHE II [points] & 27.0 & 4.2 & 21.0 & 37.0 \\
Cooling [h] & 12.3 & 6.2 & 4.0 & 32.0 \\
Fever recurrence [h] & 8.9 & 7.1 & 0.0 & 23.0 \\
Temperature $\left[{ }^{\circ} \mathrm{C}\right]$ & 39.0 & 0.3 & 38.4 & 39.8 \\
\hline
\end{tabular}

M - arithmetic mean; SD - standard deviation; APACHE II score.

Table 2. Descriptive statistics - Group 2

Tabela 2. Charakterystyka opisowa - grupa 2

\begin{tabular}{|l|r|r|r|c|}
\hline Item & M & SD & Min. & Max. \\
\hline Age [years] & 64.4 & 17.0 & 24.0 & 91.0 \\
APACHE II [points] & 27.5 & 7.4 & 11.0 & 41.0 \\
Cooling [h] & 7.9 & 4.9 & 2.0 & 25.0 \\
Fever recurrence $[\mathrm{h}]$ & 7.4 & 6.7 & 0.0 & 23.0 \\
Temperature $\left[{ }^{\circ} \mathrm{C}\right]$ & 38.7 & 0.4 & 38.3 & 39.9 \\
\hline
\end{tabular}

\section{Fever recurrence}

\section{regarding the cooling technique used}

Recurrence of fever $24 \mathrm{~h}$ after the end of the cooling procedure was observed in 24 (80\%) patients in Group 1, cooled with the Blanketrol III cooling device. Among the patients in Group 2, who were cooled with cooling gel pads, it was observed in 2 patients less, i.e., 22 (73.33\%). No statistically significant difference was observed between the groups for the cooling technique used and fever recurrence within $24 \mathrm{~h}$ after the end of cooling (Table 3 ).

\section{Period of fever recurrence regarding the duration of external cooling}

Two categories of study subjects were defined in Group 1. Among the patients cooled for 1-9 h, fever recurrence within $0-5 \mathrm{~h}$ was observed in 4 (40\%) patients, within $6-10 \mathrm{~h}$ in 1 patient only (10\%), and within more than $10 \mathrm{~h}$ in $5(50 \%)$ study subjects. Among the patients cooled for $\geq 10 \mathrm{~h}$, fever returned in 2 (10\%) patients within $5 \mathrm{~h}$ after the end of the cooling procedure, in 9 (45\%) patients within $6-10 \mathrm{~h}$, and in $9(45 \%)$ patients within more than $10 \mathrm{~h}$.

When observing the dependence of time of fever recurrence on the duration of cooling in Group 2, the following results were obtained: among the patients cooled for $1-9 \mathrm{~h}$, recurrence of fever within $5 \mathrm{~h}$ after the end of the cooling procedure was observed in 3 (15\%) patients, within $6-10 \mathrm{~h}$ in $9(45 \%)$ patients, and after $10 \mathrm{~h}$ in $8(40 \%)$ patients. Among the patients cooled for $\geq 10 \mathrm{~h}$, fever returned within $5 \mathrm{~h}$ after the end of cooling in $5(50 \%)$ patients, within $6-10 \mathrm{~h}$ in $3(30 \%)$ patients, and within $10 \mathrm{~h}$ in $2(40 \%)$ patients. No statistically significant difference was observed in any of the groups regarding to the duration of the cooling procedure. Thus, it is possible to conclude that the duration of cooling does not affect fever recurrence in any way (Table 4,5 ).

Table 3. Fever recurrence in groups

Tabela 3. Nawrót gorączki w poszczególnych grupach

\begin{tabular}{|l|c|c|c|c|}
\hline \multirow{2}{*}{ Cooling technique } & \multicolumn{2}{|c|}{ Fever recurrence } & \multirow{2}{*}{ Total } & \multirow{2}{*}{$p$} \\
\cline { 2 - 3 } & no & yes & & \\
\hline Group 1 & 6 & 24 & 30 & \\
f [\%] & 20.00 & 80.00 & 100.00 & \\
Group 2 & 8 & 22 & 30 & \multirow{2}{*}{0.542} \\
$\mathrm{f}[\%]$ & 26.67 & 73.33 & 100.00 & \\
Total & 14 & 46 & 30 & \\
$\mathrm{f}[\%]$ & 23.33 & 76.67 & 100.00 & \\
\hline
\end{tabular}

$f-$ absolute frequency.

Table 4. Influence of cooling duration on fever recurrence - Group 1

Tabela 4. Wpływ czasu ochładzania na nawrót gorączki - grupa 1

\begin{tabular}{|l|c|c|c|c|}
\hline \multirow{2}{*}{$\begin{array}{l}\text { Group 1 } \\
\text { - duration of cooling }\end{array}$} & \multicolumn{2}{|c|}{ Fever recurrence } & \multirow{2}{*}{ Total } & $\mathrm{p}$ \\
\cline { 2 - 3 } $1-9 \mathrm{~h}$ & $\mathrm{no}$ & yes & & \\
$\mathrm{f}[\%]$ & 40.00 & 60.00 & 100.00 & \\
\hline $10 \mathrm{~h}$ & 2 & 18 & 20 & \multirow{2}{*}{0.141} \\
$\mathrm{f}[\%]$ & 10.00 & 90.00 & 100.00 & \\
\hline Total & 6 & 24 & 30 & \\
$\mathrm{f}[\%]$ & 20.00 & 80.00 & 100.00 & \\
\hline
\end{tabular}

Table 5. Influence of cooling duration on fever recurrence - Group 2

Tabela 5. Wpływ czasu ochładzania na nawrót gorączki - grupa 2

\begin{tabular}{|c|c|c|c|c|}
\hline \multirow{2}{*}{$\begin{array}{l}\text { Group } 2 \\
\text { - duration of cooling }\end{array}$} & \multicolumn{2}{|c|}{ Fever recurrence } & \multirow{2}{*}{ Total } & \multirow{2}{*}{$\mathrm{p}$} \\
\hline & no & yes & & \\
\hline $\begin{array}{l}1-9 h \\
f[\%]\end{array}$ & $\begin{array}{c}3 \\
15.00\end{array}$ & $\begin{array}{c}17 \\
85.00\end{array}$ & $\begin{array}{c}20 \\
100.00\end{array}$ & \multirow{3}{*}{0.078} \\
\hline $\begin{array}{l}\geq 10 h \\
f[\%]\end{array}$ & $\begin{array}{c}5 \\
50.00\end{array}$ & $\begin{array}{c}5 \\
50.00\end{array}$ & $\begin{array}{c}10 \\
100.00\end{array}$ & \\
\hline $\begin{array}{l}\text { Total } \\
\text { f [\%] }\end{array}$ & $\begin{array}{c}8 \\
26.67\end{array}$ & $\begin{array}{c}22 \\
73.33\end{array}$ & $\begin{array}{c}30 \\
100.00\end{array}$ & \\
\hline
\end{tabular}




\section{Discussion}

High fever may be responsible for negative consequences among patients in intensive care, and suppressing high fever may improve patient survival. ${ }^{6}$ The etiology of fever in critically ill patients varies, and may be of infectious as well as non-infectious etiology. The definition of fever is also not uniform, and is presented differently by various authors. The average body core temperature in healthy individuals is between 36 and $37^{\circ} \mathrm{C}$, with minor oscillations during the day. ${ }^{7}$ The Society of Critical Care Medicine and the Infectious Disease Society of America suggest that temperatures exceeding $38.3^{\circ} \mathrm{C}$ should be considered a fever, and should call for a clinical assessment. ${ }^{5}$ Reactions of physicians and other healthcare professionals vary, depending on the institution where they work. ${ }^{8}$ Another trend is to avoid administration of external cooling if possible, depending on the patient's condition. That is also why the groups in our study are not numerous. In the Ostrava Municipal Hospital, cooling gel pads as well as the Blanketrol III cooling device are used for cooling of patients. When comparing the use of external cooling between the 2 healthcare institutions, it is possible to observe a different approach to fever suppression in patients with sepsis. In Ostrava Municipal Hospital, external cooling was applied in patients with an average body temperature exceeding $38.7^{\circ} \mathrm{C}$, whereas in the Ostrava University Hospital, external cooling was indicated in patients with an average body temperature over $38.9^{\circ} \mathrm{C}$. The use of cooling gel pads also depends on the approach of the nurse. The time of exchanging the already heated pads for newly cooled ones is very individual. Also, it is very difficult to estimate the functionality of cooling when using cooling gel pads. Marik describes the influence of external cooling using cooling mattresses on timely fever recurrence in patients with external cooling. ${ }^{3}$ When comparing our 2 study groups, we observed fever recurrence within $24 \mathrm{~h}$ after the end of the cooling procedure in $80 \%$ of patients in Group 1 , and in $73.33 \%$ of patients in Group 2. No statistically significant difference was observed between the 2 groups. Thus, it is possible to conclude that no difference exists in fever recurrence between patients cooled with the Blanketrol III cooling device and patients cooled with gel pads. Cooling gel pads present a traditional method of cooling in febrile patients; they are usually applied to the groin area, the axilla and on the neck. Nevertheless, this cooling technique may seem rather obsolete - it provides no possibility of controlling the evenness of cooling and the speed of cooling, as well as of maintaining the required temperature. Studies performed so far confirm that it is very difficult to determine which of the most commonly used physical techniques is the best. ${ }^{6}$

According to Škulec, the simplest and most frequently used technique of patient cooling is the administration of ice-cold poultices. The speed of cooling is low, reach- ing about $0.3-0.8^{\circ} \mathrm{C} / 60 \mathrm{~min}$, and, this technique being a simple "manual", it is very difficult to administer the correct dose of cooling pads. Cooling of the body surface and central compartments may be inconsistent, and no feedback regulation of cooling is possible. ${ }^{9}$

Schortgen et al. in their study, used external cooling in patients for a period of $48 \mathrm{~h}$, in order to maintain normothermia. ${ }^{10}$ In the study performed by Nichani et al., fever recurrence was a commonly observed finding. Forty patients manifested temperatures exceeding $37.5^{\circ} \mathrm{C}$ within $48 \mathrm{~h}$ after the end of the rewarming process. ${ }^{11}$ Pichon et al. described reaching normothermia in $13.5 \mathrm{~h}$ on average. ${ }^{12}$ Fever recurrence was defined as a body temperature of $38.5^{\circ} \mathrm{C}$ or higher, and was observed in $25(74 \%)$ patients within the first $24 \mathrm{~h}$ following the end of external cooling. ${ }^{12}$ The study performed by Felberger et al. presented an average duration of cooling of $5 \mathrm{~h}$ required to reach the desired temperature. The patients were cooled with two cooling pads, and with ice applied to the groin area, together with gastric irrigation using ice-cold physiological solution. The physicians managed to maintain the desired temperature in $91.7 \%$ of patients for a period of $24 \mathrm{~h}$ from the end of the cooling procedure. It is interesting to note that all patients experienced the rebound phenomenon of fever. ${ }^{13}$

In the presented research performed by the authors, the patients were cooled using external cooling techniques, either the Blanketrol III cooling device, or cooling gel pads. The average duration of cooling in Group 1 was $12.3 \mathrm{~h}$ (range $4-32 \mathrm{~h}$ ). Patients in Group 2 were cooled for an average period of $7.9 \mathrm{~h}$ (range 2-25 h). The aim of the procedure was to achieve normothermia. External cooling was terminated upon reaching the normal body temperature. There were 2 categories in Group 1. Among patients who were cooled for the period of $1-9 \mathrm{~h}$, fever returned in $40 \%$ within $5 \mathrm{~h}$. In $10 \%$ of patients, fever recurrence was observed within $6-10 \mathrm{~h}$, and in $50 \%$ of patients, fever returned after more than $10 \mathrm{~h}$. Among the patients cooled for $\geq 10 \mathrm{~h}$, fever returned within $5 \mathrm{~h}$ in $10 \%$ of patients. In $45 \%$ of patients, fever recurrence was observed after $6-10 \mathrm{~h}$, and the same applies to the group of patients with fever recurrence observed after more than $10 \mathrm{~h}$. Statistical analysis revealed no significant difference in fever recurrence in relation to the duration of cooling in Group 1.

Among the patients in Group 2 cooled with cooling gel pads, fever recurrence within $5 \mathrm{~h}$ from the end of the cooling procedure was observed in $15 \%$ of patients cooled for a period of 1-9 h; fever returned after 6-10 h in $45 \%$ of patients, and after more than $10 \mathrm{~h}$ in $40 \%$ of patients. Among the patients cooled for $\geq 10 \mathrm{~h}$, fever returned within $5 \mathrm{~h}$ in $50 \%$ of patients. Recurrence of fever after 6-9 h was observed in $30 \%$ of patients, and after more than $10 \mathrm{~h}$ in $40 \%$ of patients.

The results of this study show that no statistically significant difference exists between the cooling procedure 
using the Blanketrol III cooling device and cooling gel pads. Both these cooling techniques were associated with significant rates of fever recurrence. This poses a question concerning the sense of external cooling in patients. Another question is the use of the Blanketrol III cooling device, when the research revealed no significantly more effective cooling effect associated with the use of this device. Furthermore, the influence of duration of cooling on fever recurrence within $24 \mathrm{~h}$ after the end of the cooling procedure was not confirmed. Recurrence of fever within $24 \mathrm{~h}$ after the end of the cooling procedure, regardless of whether the Blanketrol III cooling device or cooling gel pads was used, was observed in most patients in both groups. This conclusion poses questions concerning the need for external cooling and the cooling technique which should be used.

\section{Conclusions}

In this prospective study, the authors compared the external cooling of patients in 2 hospitals in Ostrava. The Blanketrol III cooling device is generally used for external cooling of patients at intensive care units at the Ostrava University Hospital, either in patients with guided hypothermia, or in febrile patients with sepsis. The use of external cooling is strictly indicated by the attending physician. It is possible to observe a decrease in cooling procedures among patients with sepsis. The authors observed approximately equal rates of fever recurrence in both groups studied. Thus, it is possible to conclude that no significant difference exists between cooling patients using the Blanketrol III cooling device, with placement of a blanket with circulating water on the whole body surface of the patient, and the administration of cooling gel pads to the groin area, the axilla and near the head.

The whole body of the patient is being cooled when using the Blanketrol III cooling device, including upper and lower extremities. In cases when the staff wish to use this kind of cooling, it is necessary to bear in mind the possibility of numerous complications, such as the inability to measure $\mathrm{O}_{2}$ saturation at the periphery, and development of pressure ulcers on fingers, toes and in the sacral area of the spine.

The authors confirmed their hypothesis that no significant difference would be observed between the group of patients cooled with the Blanketrol III cooling device and with cooling gel pads regarding the duration of cooling. Fever returned within $24 \mathrm{~h}$ in both groups of patients, regardless of the duration of cooling.

The availability of equipment in the individual healthcare facilities plays an important role in the administration of cooling in febrile patients, i.e., whether the departments are equipped with individual instruments for external cooling or can use cooling gel pads only.

\section{References}

1. Cunha BA, Shea KW. Fever in the intensive care unit. Infect Dis Clin North Am. 1996;10(1):185-209.

2. Arons MM, Wheeler AP, Bernard GR, et al; Ibuprofen in Sepsis Study Group. Effects of ibuprofen on the physiology and survival of hypothermic sepsis. Crit Care Med. 1999;27(4):699-707.

3. Marik PE. Fever in the ICU. Chest. 2000;117(3):855-869.

4. Winters S, Wolf K. Incidence and risk factors of post-rewarming "rebound hyperthermia" in cardiac arrest patients undergoing therapeutic hypothermia. Ann Emerg Med. 2011;58(4):S185.

5. O'Grady NP, Barie PS, Bartlett JG, et al; Infectious Diseases Society of America. Guidelines for evaluation of new fever in critically ill adult patients: 2008 update from the American College of Critical Care Medicine and the Infectious Diseases Society of America. Crit Care Med. 2008;36(4):1331-1341.

6. Kiekkas P, Filos KS, Karanikolas M, Aretha D, Baltopoulos GI. Relationships between fever and outcome in intensive care unit patients. Crit Care Med. 2008;12(36):3127-3128.

7. Jirák Z. Fyziologie pro bakalářské studium na FZS OU [in Czech]. Ostrava, Czech Republic: University of Ostrava; 2009: 250.

8. Ryan M, Levy M. Clinical review: Fever in intensive care unit patients. Crit Care. 2003;7(3):221-225.

9. Škulec R, Truhlář A, Oštádal P. Současné ochlazovací metody pro indukci hypotermie po srdeční zástavě [in Czech]. Vnitřní lékařství. 2009;55(11):1060-1069.

10. Schorgoten F, Clabault K, Katsahian S, et al. Fever control using external cooling in septic shock: A randomized controlled trial. Am J Respir Crit Care Med. 2012;185(10):1088-1095.

11. Nichani R, McGrath B, Owen T, et al. Cooling practices and outcome following therapeutic hypothermia for cardiac arrest. JICS. 2012;13(2):102-106.

12. Pichon N, Amiel JB, François B, Dugard A, Etchecopar C, Vignon P. Efficacy of and tolerance to mild induced hypothermia after out-of-hospital cardiac arrest using an endovascular cooling system. Crit Care. 2007;11(3):R71.

13. Felberger RA, Kriegerd W, Chuang R, et al. Hypothermia after cardiac arrest: Feasibility and safety of an external cooling protocol. Circulation. 2001;104(15):1799-1804. 